\title{
The Influence of Decision-Making Quality on Perceptions of Foreign Grant Accountability
}

Nisfatul Izzah ${ }^{1 *}$,

Bhenu Artha ${ }^{2}$

${ }^{1}$ Accounting Study Program, Faculty of Economics, Widya Mataram University, Yogyakarta, Indonesia

2 Entrepreneurship Study Program, Faculty of Economics, Widya Mataram University, Yogyakarta, Indonesia

\begin{tabular}{|c|c|}
\hline ARTICLE INFO & ABSTRACT \\
\hline $\begin{array}{l}\text { ISSN: 2723-1097 } \\
\text { Keywords: } \\
\\
\text { Accountability, } \\
\text { Decision-Making } \\
\text { Quality, Perceptions } \\
\text { of Foreign Intangible } \\
\text { Assets (;). }\end{array}$ & $\begin{array}{l}\text { The Indonesian government and other non-profit organizations have received } \\
\text { many foreign grants, one of which is the Global Fund AIDS Tuberculosis and } \\
\text { Malaria (GFATM) grant. As the recipient of the Sub Recipient TB Care 'Aisyiyah } \\
\text { grant, East Java has an absolute obligation to account for the funds received. One } \\
\text { of its obligations is to present accountable financial statements. However, achieving } \\
\text { accountability is not easy. There is a long process with strict terms and conditions } \\
\text { from donors. These terms and conditions make institutions and financial statement } \\
\text { providers sometimes feel bored and accountability more difficult to realize. Factors } \\
\text { of human resources, tasks, and the environment are the benchmarks for an } \\
\text { accountant of foreign grants to have a strong perception of the importance of } \\
\text { accountability. } \\
\text { This study aims to determine the perception of accountants in assessing the } \\
\text { accountability of financial statements as an expense or an asset. A qualitative } \\
\text { method was used with an emphasis on interviews. The findings showed that the } \\
\text { accountability of the financial statements of foreign grants was assessed as } \\
\text { intangible assets because the recipients could benefit from the grants financially } \\
\text { and non-financially. The finance staff benefited from the accounting field as well as } \\
\text { general knowledge about tuberculosis and extensive networking in various sectors. }\end{array}$ \\
\hline
\end{tabular}

\section{Introduction}

Indonesia is a country with the world's third-largest case of infectious tuberculosis (TB or TBC) after India and China (World Health Organization, 2020). However, the government's budget has not been sufficient to handle this case, so it is still very dependent on foreign grants from GFATM (Global Fund AIDS Tuberculosis and Malaria). The Indonesian government's TB control budget for 2009--2012 only ranged from $11.2 \%$ to $34.7 \%$ compared to the funds contributed by GFATM (Setiawan et al.,

Journal of Business and Management Review Vol. 2, No. 92021 Page 648-664

DOI: $10.47153 /$ jbmr29.2232021

*Corresponding Author

Email address: Nisfatulizzah@gmail.com 
2016). This phenomenon encouraged Indonesia, represented by the Ministry of Health of the Republic of Indonesia with two other Principal Recipients (PR) (the University of Indonesia (UI) and the Central Executive 'Aisyiyah (PPA)) to take part in the management of GFATM grants.

PRs have goals and obligations in the prevention and treatment to reduce morbidity and mortality in TB patients. Sapar et al. (2020) show that the TB care community 'Aisyiyah Sulawesi has a relatively low role in treatment because it is the task of the community health center to give treatment. The role of the TB care community 'Aisyiyah is reflected in several indicators, namely early detection of TB suspects, giving advocacy, mobilization, motivating, eliminating the stigma of people with $\mathrm{TB}$, and giving assistance in taking medication for TB patients.

From 2009 to early 2021, PPA through the PR of TB Care 'Aisyiyah and Sub Recipients (SR) throughout Indonesia and Sub-Sub Recipients (SSR) in cities or districts must be able to account for the managed grants. Various strict rules and regulations from donors are related to the accountability process of financial statements. Accountability affects the recipient's ability to continue to survive with the funds needed. Without accountability, funds can be terminated at any time.

Research shows that accountability is an indicator of the realization of good corporate governance (Sarpong \& Bein, 2021). Accountability shows a positive impact on controlling the malaria epidemic and improving the quality of life in both oil and non-oil producing countries in sub-Saharan Africa for 2005-2017. Accountability efforts by continuously improving the Ethical and Integrity (E\&I) Framework and anticorruption framework, including effective fraud detection and prevention mechanisms, and ensuring duty of care or regulations that can secure the organization and its members from all parties.

Accountability of financial statements as an important form of accountability of recipient institutions has not been realized by most of the grant managers. Some of them consider their responsibility only to pay off the grants received. Several NonGovernmental Organizations (NGOs) in India are still busy enriching themselves rather than improving their accountability (Singh \& Soral, 2011). Because of this perception, accountability becomes a heavy "burden or compulsion" to be implemented.

Previous studies on foreign grants have so far discussed little, specifically in terms of financial statement accountability to NGOs. Several studies on foreign grants include questioning social sciences such as research that examines from the sociology perspective (Puteranto, 2015). This study discusses the strategy of organizing health institutions in the management of the HIVAIDS Global Fund program managed by Nahdhotul Ulama. It explores three things, namely the interaction of values and

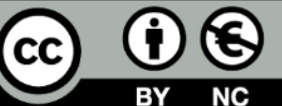

649 | P a g e

Article's contents are provided on a Attribution-Non Commercial 4.0 Creative commons license. To see the complete license contents, please visit http://creativecommons.org/licenses/by-nc/4.0/ 
norms, efforts to build organizational legitimacy, and the organization's ability to perform knowledge management.

Another foreign grant research compares the equivalence of the dependence on foreign grant aid with public policies issued by council members in Malawi (Seim et al., 2020). Meanwhile, research on the perception of accountability that offers the main concept of beneficiary accountability (BA) in the literature review shows that there are multidimensional and varied perceptions, meanings, sizes, and forms in different levels of relation to accountability (Dewi et al., 2019).

Therefore, this study aimed to find out to what extent the perception of foreign grant accountants of GFATM at SR TB Care 'Aisyiyah East Java is on the meaning of financial statement accountability. This raises a question of what the perception of foreign grant finance staff on the accountability of financial statements is. Is it an expense or an asset? This question is addressed to financial staff because they are the providers of financial statements as the main source in initiating accountable financial statements. Despite the high pressure and very small opportunity to commit fraud, if a good perception of accountability is not built early, it would allow for counterproductive actions that could harm the entire grant management team. An understanding of accountability should be given to accountants since college (Apsari, Aprilia Kartika; Suhartini, 2021).

Empirically, it is hoped that this study could give a clear perception of the size and form of financial statement accountability expected by parties related to GFATM foreign grants, so the perception of financial staff on accountability is important to examine. This study aims to describe and explore foreign grant finance staff perceptions of financial statement accountability by identifying the factors of decisionmaking quality as a reinforcement of the accountability perception of foreign grant financial statements as an expense or an asset.

\section{Literature Review}

Foreign aid is defined as the number of funds given by a developed country to poor and developing countries (Gilpin, 2016). It is also defined as grant funds as a process of transferring money, goods, technology, or technical advice from the donor country to the recipient (Holsti, 1995). Seim et al., (2020) mention that aid can be in the form of political, educational development, and underprivileged family aids. In general, foreign grant aid does not affect interest rates and liquids in the banking sector, trade openness, and the rule of law (Agapova \& Vishwasrao, 2020).

The recipient has a consequence to be responsible for the funds managed in the form of financial statement accountability. Accountability, specifically in accounting, was popularized by Lawton and Rose in 2000 as a reporting of work activities by a person or an organization for which they are responsible. If accountability is not implemented,

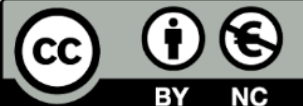

650 | P a g e

Article's contents are provided on a Attribution-Non Commercial 4.0 Creative commons license. To see the complete license contents, please visit http:/ / creativecommons.org/licenses/by-nc/4.0/ 
it will be a problem within the organization, and if it uses the other party's funds, it will be a problem between the recipient institutions and donors. Poor accountability and corruption cultures have become endemic in the management of the public sector in Nigeria (Ejere, 2012).

Meanwhile, in the principle of good corporate governance, accountability is the leader's responsibility regarding decisions and results related to the authority that can be delegated to subordinates. Accountability, in this case, becomes a control system for all elements to carry out their functions properly. Moldalieva, (2021) Critical analysis of the transparency and accountability of environmental financial reporting can improve livelihoods by directly involving community youth activists in the political economy agenda. Shields et al., (2021) show that the accountability process creates a significant burden, which is time-consuming work for the staff and growing complex power dynamics.

Financial statements can function as decision-making and a form of accountability. For the two functions of financial statements to run properly, a reliable financial statement provider who masters the financial system, financial rules, and is an honest professional with the ability to make the right accounting decisions is needed.

One of the importance of accountability is to prevent fraud and corruption which can lead to misuse of funds. The actions taken can be in the form of anti-corruption, transparency, and accountability (ACTA) to strengthen supervision and direction to the board of directors (Chang \& Kohler, 2020). This is a form of the Global Fund's accountability to adopt a strict risk management framework and work with risk mitigation into all aspects of the function (Sarpong \& Bein, 2021). The E\&I Framework can increase the disclosure of conflicts of interest and ethics.

Meanwhile, to raise awareness on the importance of accountability, the implementing team should have a common perception to facilitate two-way communication between donors and recipient institutions starting from the finance staff. Accountability is abstract and involves certain risks or difficulties (Boston \& Gill, 2011). Good accountability will have good benefits while bad accountability can provide sanctions for those who have responsibility. In the public sector, this problem can discourage some parties from carrying out accountability, so collaboration between teams is needed to realize responsible work.

Equality of perception, in this case, is a general perception which means the point of view or opinion of each person on the same thing. Perception may have different meanings from one to another, so the results of perception in this study are not necessarily used as a benchmark for overall meaning.

Experts have varied perspectives on perception. Perception is the experience of objects, events, or relationships obtained by inferring information and interpreting

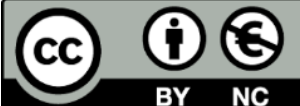

651 | P a g e

Article's contents are provided on a Attribution-Non Commercial 4.0 Creative commons license. To see the complete license contents, please visit http://creativecommons.org/licenses/by-nc/4.0/ 
messages (Rakhmat, 2011). Sumardi, (2013) defines perception as the process of receiving a stimulus through the senses, called the sensory process. Perception can also be defined as a process of giving meaning to information on a stimulus obtained from sensing events and objects that are processed by the brain (Sumanto, 2014).

Perception here uses a study of decision-making factors consisting of person, task, and environment variables. These variables are referred to as factors that can affect the quality of accounting decision making with the presence of judgment or opinions, estimates, and the formation of ideas in advance for the benefit of financial statement providers, auditors, and internal organizational managers, as well as investors (Hartono, 2019).

Shamim et al. (2019) examine the antecedents and influence of big data decisionmaking on decision-making quality among Chinese firms. Decision-making ability is affected by big data management challenges, such as leadership, talent management, technology, and organizational culture. Furthermore, big data management challenges are a major factor in the quality of decision-making.

Meanwhile, ethical decision-making can be influenced by the intensity of morals, ethics, and personal interests. Low moral intensity underlines low decision-making effectiveness and, therefore, leads to inappropriate ethical decision-making processes and behavior. Auditors need to understand the importance of decision-making skills by prioritizing ethical orientation to understand ethical dilemmas and the importance of moral intensity (Johari et al., 2017). On the other hand, the effects of similarity in characteristics, the experience of management team members, strategic mental preferences, and risk perceptions influence strategic decision making ( $\mathrm{Wu}$ et al., 2017). Companies must consider factors related to team members in addition to objective factors such as market transactions and company resources.

Decision making is defined from the explanations of experts like Bonner (1999) and Bar-Eli et al. (2011) and Trotman et al. (2011) as an act of thinking about the issues at hand and as a process of making the best choice from the consequences of various alternatives and evaluating the consequences of an object's mind (judgment) ( $\underline{2019}$ ). Judgment is defined as the formation of ideas, opinions, statuses, and estimates of a phenomenon object. From this meaning, the meaning of decision-making relates to judgment. Judgment is considered the main input in decision-making.

Several factors influence decision-making (Hartono, 2019). The first variable is the person, namely the decision-maker as the party believed to influence judgment including knowledge, experience, information processing, decision aids, and prior beliefs. The second variable is task, which is a variable related to task dimensions, such as presentation format, task complexity, and risk. The three environmental variables consist of time pressure, internal control, corporate governance, and accountability.

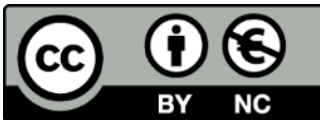

$652 \mid \mathrm{P}$ a g e

Article's contents are provided on a Attribution-Non Commercial 4.0 Creative commons license. To see the complete license contents, please visit http:/ / creativecommons.org/licenses/by-nc/4.0/ 
Meanwhile, Chaniago (2017) cites the definition of decision-making from several experts. George R. Terry and Chester Bernard define decision making as selecting one of two or more alternatives as the best solution and as the application of techniques to streamline the options that need analysis.

For financial statement providers, the quality factors of decision-making can help determine the accounting method and the format of financial statement presentations. For auditors, decision-making is used to determine financial statement opinions, and for managers, it is usually used to make business decisions. For investors, decisionmaking is usually used to determine stock transactions.

Meanwhile, process accountability in presenting financial statement information is very influential on management accountant decision making ( $\underline{\text { Rausch \& Brauneis, }}$ 2015). First, individual decision-making is the basis for further decision-making. Second, the objectives and standards of job descriptions and duties for management accountants are often unclear and contain multiple interpretations. Third, the results cannot be fully assessed as individual performance if the manager does not check the quality or the process of making management accounting. Process accountability affects the choice of management accounting information; it can be an appropriate control mechanism for the performance of management accountants.

\section{Method}

This study is descriptive qualitative research with an interview as the research instrument. (Elliott et al., 2020; Fässler et al., 2020; Nickel et al., 2020; Onchonga et al., 2020; Schneeberger et al., 2020; Soilemezi et al., 2020; Utne et al., 2020). There were three types of interviews, namely structured, semi-structured, and unstructured interviews. The questionnaires consisting of closed questions that require factual data were provided via email.

It used a case study approach in the Sub-Recipient TB-HIV Care 'Aisyiyah East Java. The informants were 7 SSR financial staff as key informants and 3 supporting informants. The names of the informants were coded for confidentiality. The criteria for informants were those working for at least 5 years and the representatives of cities or regencies that became the first implementers of the grant program. This study aims to describe, summarize, explain various conditions and situations or phenomena regarding the perception of the accountability of the Global Fund grants, as well as attempt to draw the existing reality as an overview of the phenomenon. (Bungin, 2014)

\section{Result and Discussion}

Accountability of the foreign grant financial statements is an absolute obligation for the recipient institutions. Therefore, they need to prepare accountability as well as possible for continuous grants as needed. Accountants are the main instrument in realizing financial accountability. The implication of this study is an unprecedented 
thinking method of finance or finance administration (FA) staff so that they know a new perspective that needs to be built on the meaning of accountability.

Accountability of GFATM foreign grant financial statements raises awareness to understand the activities of managing grant funds with the assumption that it not only becomes a routine to complete financial evidence but also has changed the perception of accountability that can encourage someone to make financial statements professionally and find added value as intangible assets. Broadly speaking, the researchers have identified three themes that emerged from the analysis of interview data related to perceptions of accountability, and each sub-theme is according to the experience of the informants.

\section{1) Person (Financial Statement Provider) Variable}

The characteristics of financial statement providers differ from one another according to their knowledge, experience, and information processing. There were 7 informants in the study. Most of them previously worked in non-grant organizations; 5 people worked in for-profit organizations; 1 person had experience as a manager of grant funds from the World Bank; the other has never worked at all. Their educational background varies. There were accounting graduates, a mathematics graduate, and an agriculture graduate. This education affects the understanding of accounting but does not affect the understanding of accountability.

\section{2) Task Variable}

The initial reaction of the financial staff when they learned about the accounting system (procedure) of the GFATM foreign grant accounting statements varied. Some staff was confused because it was their first time working and they were immediately faced with numerous, complete, and strict reporting tasks. Most of them considered the statement system and format to be standard. However, there is still much to be learned because there are many terms and supporting documents that are very different from financial statements for for-profit institutions.

To find out the difference between the activity of making financial statements of grants and general knowledge or experience in presenting financial statements of forprofit organizations, a question was asked. "In your opinion, is there a specific thing in making financial statements of Global Fund grants compared to those of organizations or companies in general? If so, please specify." The results showed that two informants stated nothing specific. This perception is due to a reasonable assumption that each organization or donor has its methods and rules. The goals of for-profit and non-profit organizations are incomparable. The five FA SSRs stated that there were specific things. According to them, the specific things are:

(a) The type of financial statements, in which there is no profit and loss financial statement so that the focus is on the absorption of funds;

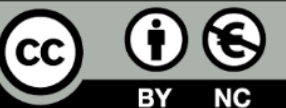

654 | P a g e

Article's contents are provided on a Attribution-Non Commercial 4.0 Creative commons license. To see the complete license contents, please visit http://creativecommons.org/licenses/by-nc/4.0/ 
(b) Administration and supporting documents for financial transactions assessed in more detail so that sometimes they seem complicated;

(c) Tighter planning and budgeting; and

(d) Audits that must be faced in layers, consisting of internal audit, external audit, and big four international audits by Local Fund Agent (LFA) as part of the public accounting firm Pricewaterhouse Coopers (PWC) Geneva.

One of the main focuses of this study is to determine the level of complexity of foreign grant accounting tasks with an explanation of the structure of the tasks carried out. This leads to the following question, "Based on your experience, is the practice of foreign grant accounting difficult or easy to apply? Give reasons that clarify your perception." Five informants answered "easy", one answered "difficult", and the other answered "neutral".

They said easy mostly because the accounting system made has provided clear technical instructions and rules, making it easy to practice. Meanwhile, those who considered it difficult because compared to the provisions in the company, their previous work was simpler. The Global Fund's foreign grant terms and conditions are numerous, complex, and stringent. This is as shown by the following interview excerpts:

"At first, it was difficult because we were not used to it. Once we know the workflow, God willing, we can learn it, but we must be thorough and careful." (AR, FA SSR Bojonegoro, 2021).

“The accountability is complicated. For one activity/transaction, there are several documents to be attached. We must be disciplined because reporting must be on time and strict since all transactions must comply with applicable regulations. Funds from donors are allocated correctly and appropriately. Proofs of expenditure must be complete, accurate, and detailed. For example, when you want to purchase an item or pay for a service, you must first make a PRQ (Purchase Request), PO (Purchase Order), Analyst Bid, and so on." (SS, FA SSR Nganjuk, 2021).

\section{3) Environment Variable}

The environment in the TB Care 'Aisyiyah program is quite extensive because the environment that is involved in TB control in 'Aisyiyah is not only internal but also from various religions, ethnic cultures, socioeconomics, and varied educational

655 | P a g e

Article's contents are provided on a Attribution-Non Commercial 4.0 Creative commons license. To see the complete license contents, please visit http://creativecommons.org/licenses/by-nc/4.0/ 
backgrounds. This environment also allows financial staff to interact more broadly. However, environmental factors do not change the needs of the task but influence the effort and motivation of decision making. The environment in this study is the financial work environment.

Time pressure and pressure to comply with accounting rules, internal control, and corporate governance, as well as accountability, can affect the way of thinking of the financial staff of SR/SSR TB Care 'Aisyiyah. Productivity, motivation, job satisfaction, and teamwork can be influenced by a healthy and dynamic environment. The productivity referred to by the researcher is the will and effort of the financial staff to always improve the quality of life and livelihood in all fields, especially in work performance.

The interview results showed that financial staff had an effort to be more focused, thorough in making the financial statement, and accountable for a down payment for activities along with proof of transactions. More well-planned planning to reduce problems is lacking in reporting. The cooperation of the implementing team during the activities and accountability of the down payment of activities greatly affects the accountability of reporting. The financial staff feels satisfied with their job if the financial planning with the realization of the absorption of funds is achieved maximally. Budget realization can be achieved if all teams carry out their duties according to their respective duties and responsibilities. Timely, good, and correct financial statements, according to the results of the provincial-level financial specialist internal control reviews, as well as good audit results are prime satisfaction.

\section{4) Implications and Perception}

It is implied that this study can be a reference in management decision-making. It is not only the personal staff who determine the decision-making to improve the accountability of financial statements but there are also task and environmental factors to be mastered and carried out by the whole implementing team. After all the motivations and measures of financial statement accountability are clear, accountability cannot be realized only by relying on personal finance staff.

Using three variables of decision-making quality factors (person, task, and environment variables) (Hartono, 2019), the financial staff weighed the advantages and disadvantages of presenting the financial statements of the Global Fund grant materially and non-materially. Finance staff measured their abilities and duties. They assessed the task and its environment. They perceived based on their experience and a long process with self-capacity, many tasks, and a wide environment with a solid team. The three variables become the benchmark for the researchers to develop questions before discussing the meaning of financial statement accountability. Those questions include:

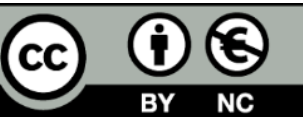

656 | P a g e

Article's contents are provided on a Attribution-Non Commercial 4.0 Creative commons license. To see the complete license contents, please visit http://creativecommons.org/licenses/by-nc/4.0/ 
First, to find out the perception of accountants on how to achieve accountability, the question "Do you think achieving financial statement accountability is easy or difficult?" was asked. Most answered that it was an easy little bit difficult. Others said it was difficult. Easy little bit difficult is interpreted as something that is easy to do but must be understood and detailed.

Second, to determine the perception of job satisfaction and motivation, the question "In your opinion, is the salary you get commensurate with the work you do?" was asked. Most FA SSR SSRs answered that it was not enough. In this section, the code names of the informants are purposely not mentioned one by one by the author.

"The workload is indeed heavy even though since 2017, the salary has been equalized with the regional minimum wage, but I hope more because of the increasing workload." (No name, FA SSR, 2021)

"When there are a lot of full activities, there are a lot of financial statements too. The salary doesn't seem to be worth the workload. Only at the beginning of the budget period is there a little light task because the activities are still about planning activities and budgeting." (No Name, FA SSR, 2021)

"Because the Global Fund is not the only foreign grant program I have ever managed, I think the salary received with the workload assigned is not balanced. It's too small." (No name, FA SSR, 2021)

Contrary to other opinions, the following two informants considered the salary to be sufficient because they compared it with the regional minimum wage. One of them has never worked before while the other has worked in the non-grant sector with a small-scale company with a salary below the minimum wage.

"For the balance between salary and workload, in my opinion, it has been per the portion because the salary given has been adjusted to the minimum wage for each city/regency of work." (No name, FA SSR, 2021)

Third, ideally a decision not only looks at what has happened but also considers something to come. Therefore, the question "Have you considered the advantages and disadvantages for your future after this program ends?" was asked

"The advantage is getting new knowledge and experience that I have never had in my previous workplace, which is a grant fund accountant in the social sector. The disadvantage is the system of contract or non-permanent work. When the donor is about to terminate the contract, we must be prepared to look for another job." (SS Finance Staff of SSR Nganjuk, 2021)

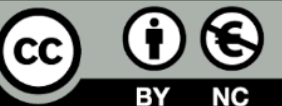

657 | P a g e

Article's contents are provided on a Attribution-Non Commercial 4.0 Creative commons license. To see the complete license contents, please visit http://creativecommons.org/licenses/by-nc/4.0/ 
A long-term advantage has also been demonstrated by former SSR FA who had quit before 2020, such as former financial staff of SSR Jombang and SSR Kediri Regency. In practice, they can apply accounting knowledge in any institution, not necessarily the same as foreign grants, more easily. The former financial staff of Kediri Regency became the executor of domestic government grants. Meanwhile, the former SSR Jombang staff felt that it was easy to make financial statements for their business. This is as shown in the following excerpt:

"The knowledge that I got from managing foreign grant funds is still very useful. After 6 months of discontinuation as Global Fund staff, I manage grant funds at the Taman Posyandu educational institution. Every semester, we receive a domestic grant in the form of Early Childhood School Operational Assistance (BOP). The basic knowledge of TB health during the training in the GFATM program is useful for me when working at Taman Posyandu now. The integrated healthcare center is intended for toddlers who are still accompanied by their parents, so I can share much information about health and PHBS behavior in general to prevent diseases such as TB, DHF, etc." (ZY Former FA SSR Kediri Regency, 2021).

"In the middle of 2017, I set up a business, so the accounting knowledge can still be used. The experience is also very useful because when I work, I meet many people so that I can promote my business." (DN Former FA SSR Jombang, 2021)

Two former staff of the SSR Global Fund were also benefited as supporting informants in this study. They are former financial staff of SSR Sidoarjo and SSR Jember. After completing the TB Care 'Aisyiyah program with the relevant Global Fund, the former Sidoarjo SSR staff was immediately accepted as UNICEF Indonesia's foreign grant finance staff in East Java. The former financial staff of SSR Jember becomes a financial staff at the hospital.

The internal researcher also has the same experience. She worked as a financial specialist at the SR East Java before becoming an accounting lecturer now. Experience as a practitioner is practically a classroom teaching material. It is a real example of accounting transactions, accounting information systems related to forms and procedures for the procurement of goods and services, as well as materials for using financial software. Moreover, the leader in financial management as the executor of duties of the second deputy dean in finance becomes makes her very adaptive and easy to lead her staff.

Likewise, insight and knowledge about the management of accountability for financial statements of NGOs which remain controversial among academics can be given in class by the researcher. As an internal researcher, she can provide real examples in this study. NGO accounting materials that are not yet available in the syllabus and specific lecturing guidelines can be given to public sector accounting 
courses to instill knowledge that public sector accounting is not only government accounting but also non-government accounting such as NGO accounting. This needs to be done considering the urgency of the NOG accountability material in increasing the understanding of academics (Cordery et al., 2019) (Hall \& O’Dwyer, 2017).

Although it is not easy to realize financial statement accountability, when asked about the meaning of financial statement accountability, the financial staff answered that it was something of value. To find out the meaning of accountability in financial statements, the researcher asked the question "What is one word that comes to your mind between the compulsion or asset that describes your feelings and perceptions about the demands for accountability for the financial statements of the Global Fund's foreign grants?" All informants have the same perspective or perception that accountability of financial statements is valued as an asset.

This perception is subjective. The findings of this study prove that although the accounting structure and design of the Global Fund grants were strict and had several shortcomings, including a relatively low salary, the SSR finance staff did not decide to leave this humanitarian program. The accounting sciences that can increase the knowledge of financial staff based on their usefulness in facilitating their work and increasing international accounting knowledge for overseas grants can be sorted as follows.

Based on the answer to the question in an email "Of the most useful accounting fields for smooth work and increasing your accounting knowledge, which one is the most influential?", financial and organizational accounting is the first choice, accounting system the second, administrative and technical reporting the third, and auditing and financial accounting the last.

What makes the financial staff continue managing this grant program is their assumption of its many advantages of intangible assets. The advantages are not only for the organization and its direct beneficiaries but also for the individual finance staff. These advantages include increasing practical accounting knowledge on an international scale, general scientific advantages in the field of TB Health, and extensive networking ranging from the Health Service, board members, businessmen, and getting to know many fellow service providers such as hotels and others.

The provincial financial specialist staff felt the same way. Although the salary has reached two to three times the minimum wage of SSR, this is not the main reason for surviving up to 10 years in the program; the advantages are greater than just money. However, the three-time higher salary is accompanied by greater tasks and risks. The risks can be many more than the risks faced by city and regency finance staff.

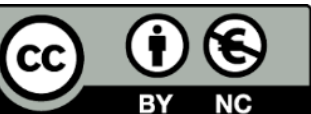
the complete license contents, please visit http:/ / creativecommons.org/licenses/by-nc/4.0/ 
The results of interviews with the financial staff of SSR Bojonegoro, Nganjuk, Jombang, Kediri, and Surabaya showed the main reason they still work in the Global Fund program with all its shortcomings.

"The reason I will work in the financial management of foreign grants is because of a very noble humanitarian program; I feel that I can be useful for others and very grateful for the opportunity to learn many things in this program." (FA SSR, 2021)

In addition to the advantage of an intangible asset such as knowledge, insight, networking, and humanitarian missions that touch their hearts, they have thought about the long-term advantages for their profession. This perspective, according to the researchers, is very good and useful for institutions that need financial statement providers in the future. Finance staff who have a positive perception will become one of the reliable human resources in foreign grant accounting. If the institution has staff who are militant, those who are strong in fighting for the organization's goals, it is a valuable wealth. The loss in the form of a relatively low salary is not the main problem. It is a risk for everyone who works as a subordinate.

\section{Conclusion}

The findings showed that the accountability of the financial statements of foreign grants was assessed as intangible assets because the recipients could benefit from the grants financially and non-financially. The finance staff benefited from the accounting field as well as general knowledge about tuberculosis and extensive networking in various sectors. The factors that strengthen the perception of financial staff on the importance of accountability as an intangible asset are influenced by three quality decision-making factors which are reflected in the person, task, and environment variables.

Empirically, this study is very useful for accountants and the management of nongovernment foreign grant managers. Because of this strong perception, financial staff has become accustomed to presenting financial statements properly and correctly without the daunting burden of which ultimately has an impact on financial reporting success stories and a good track record for the name of grant recipient institutions internationally.

Theoretically, this study has complemented the previous study (Singh \& Soral, 2011; Apsari, Aprilia Kartika; Suhartini, 2021; Dewi et al., 2019) showing that non-profit organizations do not always enrich themselves, but the perception of accountability as an intangible asset can encourage all parties to realize accountability starting from the financial staff. The understanding of accountability given since school includes elements of religion as well as human values. Thus, the size and meaning of accountability can at least be measured from the perception of accountability itself and

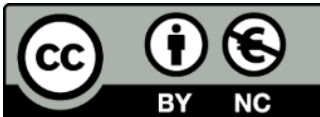

660 | P a g e

Article's contents are provided on a Attribution-Non Commercial 4.0 Creative commons license. To see the complete license contents, please visit http://creativecommons.org/licenses/by-nc/4.0/ 
is manifested in the form of seriousness in presenting accountable financial statements with militant financial staff.

Suggestions for further research are to compare recipient organizations in Indonesia and abroad, or compare the performance of grant recipient organizations in Indonesia, as has been done by previous researchers (Moreno-Albarracín et al., 2021). Future researches can also present literature reviews on accountability or perception (Khairi et al., 2021) and firm performance (Artha et al., 2021).

\section{Acknowledgment}

Thanks to Bhenu Artha as the team for writing this article

\section{References}

Agapova, A., \& Vishwasrao, S. (2020). Financial sector foreign aid and financial intermediation. International Review of Financial Analysis, 72, 101589. https://doi.org/10.1016/j.irfa.2020.101589

Apsari, Aprilia Kartika; Suhartini, D. (2021). Religiosity as Moderating of Accounting Student Academic Fraud with a Hexagon Theory Approach. Accounting and Finance Studies Vol. 1 No. 3 2021, 1(3), 211-230. https://doi.org/10.47153/afs13.1512021

Artha, B., Bahri, B., Sari, N. P., Sari, U. T., \& Manurung, U. R. (2021). The Institutional Ownership and Firm Performance: Evidence from The Capital Bank. Journal of Business and Management Review, 2(7), 445-456.

Boston, J., \& Gill, D. (2011). Joint or Shared Accountability: Issues and Options. June, $1-36$.

Bungin, B. (2014). Penelitian Kualitatif. Prenada Media Group.

Chang, Z., \& Kohler, J. (2020). The Global Fund: Anti-Corruption, Transparency and Accountability. 1-21.

Chaniago, A. (2017). Teknik Pengambilan Keputusan (pendekatan teori dan studi kasus). Jakarta: Lentera Ilmu Cendekia

Cordery, C., Belal, A. R., \& Thomson, I. (2019). NGO accounting and accountability: past, present and future. Accounting Forum, 43(1), 1-15. https:/ / doi.org/10.1080/01559982.2019.1593577

Dewi, M. K., Manochin, M., \& Belal, A. (2019). Towards a conceptual framework of beneficiary accountability by NGOs: An Indonesian case study. Critical Perspectives on Accounting, 2020. https://doi.org/10.1016/j.cpa.2019.102130

Ejere, E. S. I. (2012). Promoting accountability in public sector management in today's democratic Nigeria. Tourism and Management Studies International Conference Algarve, 3, 953-965. 
Elliott, J., DeJean, D., Potter, B. K., Coyle, D., Clifford, T., McCoy, B., \& Wells, G. A. (2020). Neurologists' perspectives on medical cannabis for pediatric drug-resistant epilepsy in Canada: A qualitative interview study. Seizure, 78(December 2019), 118-126. https:// doi.org/10.1016/j.seizure.2020.04.002 Fässler, M., Jöbges, S., \& Biller-Andorno, N. (2020). Bonus agreements of senior physicians in Switzerland - A qualitative interview study. Zeitschrift Fur Evidenz, Fortbildung Und Qualitat Im Gesundheitswesen, 158-159(2020), 39-46. https://doi.org/10.1016/j.zefq.2020.09.002

Gilpin, R. (2016). The political economy of international relations. The Political Economy of International Relations, 1-449. https:/ / doi.org/10.2307/40202522

Hall, M., \& O'Dwyer, B. (2017). Accounting, non-governmental organizations and civil society: The importance of nonprofit organizations to understanding accounting, organizations and society. Accounting, Organizations and Society, 63, 1-5. https://doi.org/10.1016/j.aos.2017.11.001 Hartono, J. (2019). Kajian Literatur dan Arah Topik Riset Ke Depan. ANDI.

Holsti, K. J. (1995). International Politics: A Framework for Analysis. New Jersey Prentice Hall.

Johari, R. J., Mohd-Sanusi, Z., \& Chong, V. K. (2017). Effects of auditors' ethical orientation and self-interest independence threat on the mediating role of moral intensity and ethical decision-making process. International Journal of Auditing, 21(1), 38-58.

Khairi, A., Bahri, B., \& Artha, B. (2021). A Literature Review of Non-Performing Loan. Journal of Business and Management Review, 2(5), 366-373. https://doi.org/10.47153/jbmr25.1402021

Moldalieva, J. (2021). Localizing transparency and accountability in extractives. The Extractive Industries and Society, August, 100991. https://doi.org/10.1016/j.exis.2021.100991

Moreno-Albarracín, A. L., Ortega-Rodríguez, C., Licerán-Gutiérrez, A., Labella, Á., \& Martínez, L. (2021). Transparency indicators to improve accountability for non-profit organizations: A Spanish case study. Technological and Economic Development of Economy, 27(3), 763-782. https://doi.org/10.3846/tede.2021.14821

Nickel, B., McCaffery, K., Houssami, N., Jansen, J., Saunders, C., Spillane, A., Rutherford, C., Dixon, A., Barratt, A., Stuart, K., Robertson, G., \& Hersch, J. (2020). Views of healthcare professionals about the role of active monitoring in the management of ductal carcinoma in situ (DCIS): Qualitative interview study. Breast, 54, 99-105. https://doi.org/10.1016/j.breast.2020.09.002

Onchonga, D., Várnagy, Á., Keraka, M., \& Wainaina, P. (2020). Midwife-led integrated pre-birth training and its impact on the fear of childbirth. A 
qualitative interview study. Sexual and Reproductive Healthcare, 25(April), 100512. https://doi.org/10.1016/j.srhc.2020.100512

Puteranto, H. (2015). Strategi Pengorganisasian Lembaga Kesehatan Nahdlatul Ulama (Lknu) Dalam Pengelolaan Program Hiv/aids (Studi Kasus Pengelolaan Dana Hibah Global Fund AIDS Di Indonesia). Jurnal Sosiologi Reflektif, 9(2). https://www.neliti.com/publications/132371/strategipengorganisasian-lembaga-kesehatan-nahdlatul-ulama-lknu-dalampengelola

Rakhmat, J. (2011). Psikologi Komunikasi. PT Remaja Rosdakarya.

Rausch, A., \& Brauneis, A. (2015). The effect of accountability on management accountants' selection of information. Review of Managerial Science, 9(3), 487521. https:// doi.org/10.1007/s11846-014-0126-8

Sapar, Salju, Risal, M., Samsinar, Zainal S, M., \& Akbar, M. (2020). The influence of TB care community cadre's roles on the treatment adherence of tuberculosis (TB) sufferers. Enfermeria Clinica, 30, 244-248. https://doi.org/10.1016/j.enfcli.2020.06.056

Sarpong, S. Y., \& Bein, M. A. (2021). Global fund and good governance in subSaharan Africa: accounting for incidence of malaria and quality of life in oil and non-oil producing countries. In SN Social Sciences (Vol. 1, Issue 8). Springer International Publishing. https://doi.org/10.1007/s43545-02100213-7

Schneeberger, A., Brandstetter, S., Bein, T., Blecha, S., \& Apfelbacher, C. (2020). Stressors and strains of next of kin of patients with ARDS in intensive care: A qualitative interview study using a stress-strain approach. Intensive and $\begin{array}{llll}\text { Critical Care } & \text { Nursing, } & \text { 57(xxxx), } & \end{array}$ https://doi.org/10.1016/j.iccn.2019.102783

Seim, B., Jablonski, R., \& Ahlbäck, J. (2020). How information about foreign aid affects public spending decisions: Evidence from a field experiment in Malawi. Journal of Development Economics, 146, 102522. https://doi.org/10.1016/j.jdeveco.2020.102522

Setiawan, E., Sucahya, P. K., Thabrany, H., \& Komaryani, K. (2016). A Comparative Budget Requirements for TB program based on Minimum standard of Services (SPM) and Budget Realization: An Exit Strategy Before Termination of GF ATM. Jurnal Ekonomi Kesehatan Indonesia, 1(1), 12-22. https://doi.org/10.7454/eki.v1i1.1761

Shamim, S., Zeng, J., Shariq, S. M., \& Khan, Z. (2019). Role of big data management in enhancing big data decision-making capability and quality among Chinese firms: A dynamic capabilities view. Information and Management, 56(6), 1-12. https:/ / doi.org/10.1016/j.im.2018.12.003

Shields, R., Banerjee, S., Shajahan, P. K., Singh, G. B., Bista, M. B., Krishna, G., 
Paudel, M., Singh, A., Hernandez, A. S., Carney, S., Kameshwara, K. K., \& Dhanda, K. R. (2021). The double pendulum: Accountability relationships and learning in urban South Asia. International Journal of Educational Development, 84(March), 102438. https://doi.org/10.1016/j.ijedudev.2021.102438

Singh, A., \& Soral, G. (2011). A Note on Accounting Education: Accounting for NGOs. EDITORIAL BOARD, 42(1), 76-79.

Soilemezi, D., Leydon, G. M., Yan, R., Simpson, C., Bell, M., Bostock, J., Moore, M., \& Willcox, M. (2020). Herbal medicine for acute bronchitis: A qualitative interview study of patients' and health professionals' views. Complementary Therapies in Medicine, 55(October), 102613. https://doi.org/10.1016/j.ctim.2020.102613

Sugiyono. (2014). Metode Penelitian Kuantitatif Kualitatif dan RED. Bandung.Alfabeta, cv.

Sumanto. (2014). Psikologi Umum. CAPS.

Sumardi, S. (2013). Psikologi Pendidikan. PT Raja Grafindo Persada.

Utne, R., Antrobus-Johannessen, C. L., Aasheim, V., Aaseskjær, K., \& Vik, E. S. (2020). Somali women's experiences of antenatal care: A qualitative interview study. Midwifery, 83. https://doi.org/10.1016/j.midw.2020.102656

World Health Organization. (2020). Are Updated Every Year. for the Tuberculosis. $\mathrm{Wu}, \mathrm{T} ., \mathrm{Wu}, \mathrm{Y}$. J., Tsai, H., \& Li, Y. (2017). Top Management Teams' Characteristics and Strategic Decision-Making: A Mediation of Risk Perceptions and Mental Models. In Sustainability (Vol. 9, Issue 12). https://doi.org/10.3390/su9122265 